\title{
ПІДЛІТКОВИЙ АЛКОГОЛІЗМ: СОЦІАЛЬНІ ФАКТОРИ РИЗИКУ
}

\author{
І. В. Лисюк, О. М. Христенко \\ Конотопське медичне училище \\ ДВНЗ «Тернопільський державний медичний університет \\ імені І. Я. Горбачевського МОЗ Украӥни"
}

У статті проаналізовано історичні аспекти проблеми алкоголізму, фактори ризику розвитку алкогольної залежності. Наведено статистичні дані дослідження з даної проблеми.

\section{TEENAGE DRINKING: SOCIAL RISK FACTORS}

\author{
I. V.Lysyuk, O. M. Khristenko \\ Konotop Medical School, \\ I. Horbachevsky Ternopil State Medical University
}

The article analyzes the historical aspects of alcoholism; risk factors for alcohol dependence. An investigation statistics on this issue is given.

Вступ. Дана робота присвячена актуальній проблемі - алкоголізму. На сьогодні вона $є$ однією $з$ найболючіших тому, що кількість людей, які зловживають алкоголем, невпинно зростає. І це негативно впливає на всі сторони особистісного, сімейного та суспільного життя (економіку, моральність, соціальні відносини). 3 кожним роком алкоголізм все омолоджується, відтак підлітковий алкоголізм як педагогічна проблема потребує, зокрема, історичного аналізу та визначення його факторів ризику.

Основна частина. Як свідчать різнопланові історичні джерела, вживання алкоголю має давню історію та традиції. Про властивості спиртних напоїв люди дізналися давно - із появою керамічного посуду, що дало можливість виготовляти алкогольні напої з меду, плодових соків і винограду. Можливо, виноробство виникло ще до початку культурного землеробства. Нам достеменно відомо, що першу пляшку горілки виготовив арабський медик і хімік Разез у 860 р.

Дослідження раннього періоду християнської Русі показали, що в ті часи тверезість була національною рисою нашого народу. Алкогольні традиції на Русі визначалися ритуальним вживанням хмільних напоїв із нагоди знаменних подій, православних свят, весіль,

(ㄱ) І. В. Лисюк, О. М. Христенко, 2017 хрестин, поминок, завершення збору врожаю тощо, i носили в цілому епізодичний характер. Але з XVI століття почалося масове завезення горілки й вина з-за кордону. Був культ не вина, а горілки, пропагувалося пияцтво за будь-яких життєвих ситуацій, починаючи від релігійних свят і закінчуючи найменшими подіями у повсякденному житті [4].

Однією з плям минулого, сліди якої ще збереглися в нас, є пияцтво й алкоголізм. Але традиції, звички мають величезну силу. Це одна з причин, чому ми поки що не можемо відмовитися від продажу горілки. Другою причиною є те, що заборона може призвести до поширення самогоноваріння, а в зв'язку з цим - до витрачання великої кількості зерна, цукру, фруктів та інших цінних продуктів, до спекуляції, до незаконного продажу спиртних напоїв, до зростання захворювань і отруєнь у результаті вживання алкогольних напоїв. Життя показало, що заборона продажу спиртних напоїв у деяких країнах не тільки не сприяє зменшенню алкоголізму, а, навпаки, як свідчить статистика, у ряді випадків збільшує пияцтво. Отже, «сухий закон» проблеми не розв'язує.

Разом з тим, понад 90 \% 15-17-річної учнівської молоді в Україні має досвід вживання алкоголю, майже 60 \% підлітків декілька разів перебували в стані 
сп'яніння. Доступною $є$ інформація щодо шкідливого впливу алкоголю, пива та енергетичних напоїв на зростаючий організм підлітків. Від алкоголю страждають усі органи і системи, насамперед, нервова, серцево-судинна, травна. Порушується стан печінки, нирок, імунна система, гормональний баланс організму. Алкоголізм у підлітків формується в стислі строки й відрізняється злоякісним, прогресуючим перебігом. Варто брати до уваги й генетичні основи формування алкогольної залежності.

Отже, найбільш сильним фактором, що впливає на ранню алкоголізацію у підлітків, є сім'я. Адже психологічний розвиток особистості підлітка відбувається головним чином тут. Особливості організму (у плані реакції на алкоголь) - теж провина сім'ї (спадковість). I, нарешті, перший досвід підліток найчастіше також отримує в сім'і [3].

Головними труднощами, що перешкоджають вихованню в молоді негативного ставлення до алкоголю $\epsilon$ існуюче сьогодні в суспільній свідомості поблажливо-добродушне ставлення до вживання алкоголю взагалі й думка про безпечне вживання алкоголю під- літками зокрема. Більше того, самі батьки, найчастіше $\epsilon$ першими «алкогольними вихователями» своїх дітей. Саме вони прищеплюють їм «питні традиції», підносячи першу чарку і вважаючи цілком припустимим вживання алкоголю підлітком.

Змінити існуюче в суспільній свідомості спокійно-поблажливе ставлення до вживання алкоголю неповнолітніми, насторожити суспільну думку щодо небезпеки вживання спиртного молоддю - справа складна, важка, але вкрай необхідна. Допоможе у цьому знання законодавства як неповнолітніми, так i їхніми батьками. У результаті анкетування з'ясовано, що 43 \% батьків дозволяють вживати легкі алкогольні напої на свята, 14 \% - не знають, що їхня дитина вживає спиртні напої. Майже всі респонденти (94\%) знають про відповідальність, яку несуть вони та їхні батьки за розпиття алкогольних напоїв.

Аналіз зібраних даних дає нам підставу зробити висновок, що молодь та їхні батьки володіють достатньою інформацією щодо відповідальності за розпивання алкогольних напоїв, але з певних причин дозволяють іноді вживати алкоголь (рис. 1).

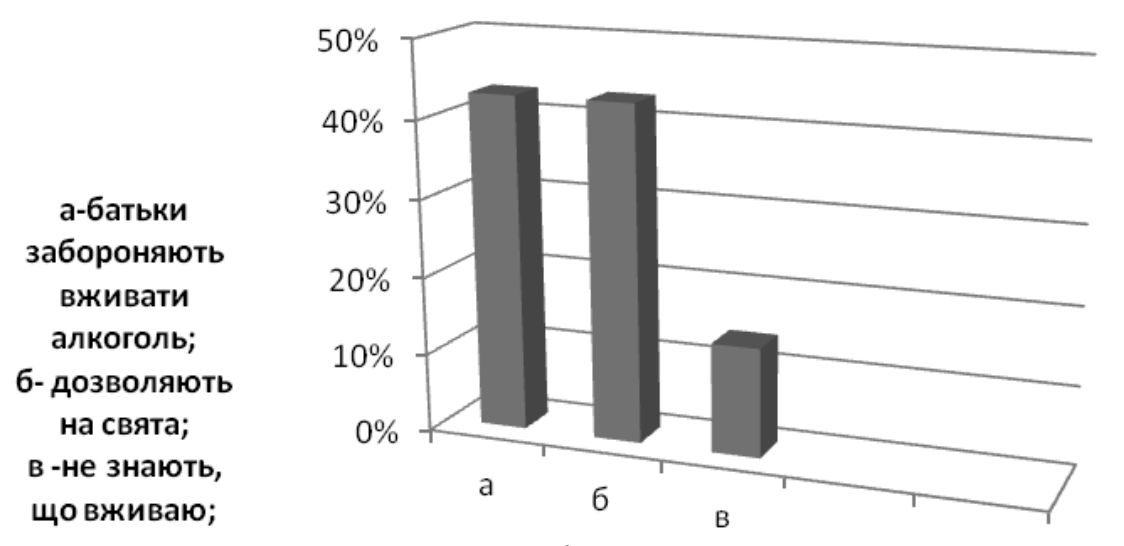

Puc. 1. Ставлення батьків до вживання алкоголю.

На рисунку 2 ми бачимо, що основне джерело отримання інформації про шкідливість алкоголю є навчаль- ний заклад (61 \%), 18 \% респондентів отримали інформацію від батьків, 11 \% - від ЗМІ, 8 \% дізналися від друзів.

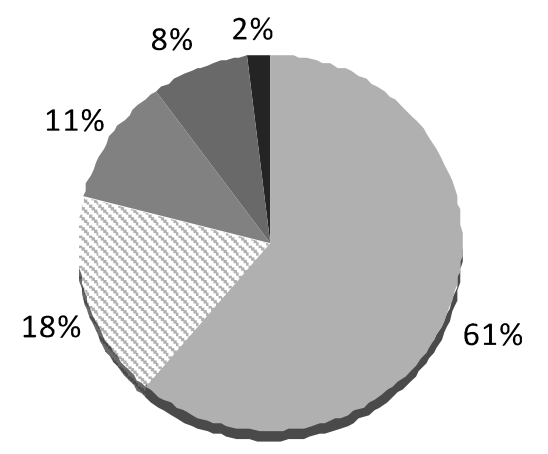

в навчальному закладі
від батьків
змІ
друзі
не знаю

Puc. 2. Джерело отримання інформації про алкоголізм. 
Рівень поінформованості про шкідливість алкоголю не має безпосереднього впливу на рівень поширеності цієї звички, проте це не означає, що такого роду інформація непотрібна. Навпаки, лише систематичні та достовірні знання спонукатимуть молоду людину замислитись над важливістю цієї проблеми, внести корективи до власного способу життя або докорінно змінити його. А завдання навчального закладу, 3МІ, дорослих - всіляко сприяти заохоченню до таких знань у молоді.

На другому місці серед факторів, які спричиняють розвиток шкідливих звичок, засоби масової інформації. На третьому - друзі. У підлітковому віці людина гостро потребує компанії і вона, звичайно ж, істотно на неї впливає.

Стосовно двох інших груп факторів - психологічних та індивідуально-біологічних, то вони мають особистісний, а не соціальний характер.

Беручи до уваги шкоду, яку завдає здоров'ю вживання алкоголю, попередження шкідливих звичок у студентів стає важливим напрямком виховальнопрофілактичної роботи навчальних закладів. Профілактична робота повинна здійснюватися нерозривно з розумовим, трудовим, фізичним і моральним вихованням. У процесі цієї роботи має формуватися гармонійно розвинена культурна особистість, важливо виховати моральні норми, формувати загальнолюдські цінності й уміння вести здоровий спосіб життя. Отже, ми з'ясували, як молодь проводить свій вільний час (рис. 3).

На формування світогляду підлітка впливають такі чинники: сім'я, авторитет батьків - 39 \%; друзі, одно-

\section{СПИСОК ЛІТЕРАТУРИ}

1. Болтівець С. І. Соціально-педагогічні причини поширення пияцтва серед молоді / С. І. Болтівець, Н. А. Фоліменко // Практична психологія та соціальна робота. - 2004. - № 10. - С. 4-6.

2. Герасименко Н. Ф. Вплив наркотиків і алкоголю на генофонд нації і майбутнє держави / Н. Ф. Герасименко // Міжвузівський зб. наук. статей. - Вороніж, 2008. - С. 10-12. літки - 29 \%; навчальний заклад, вчителі - 20 \%; 3MІ $12 \%$ (рис. 4).

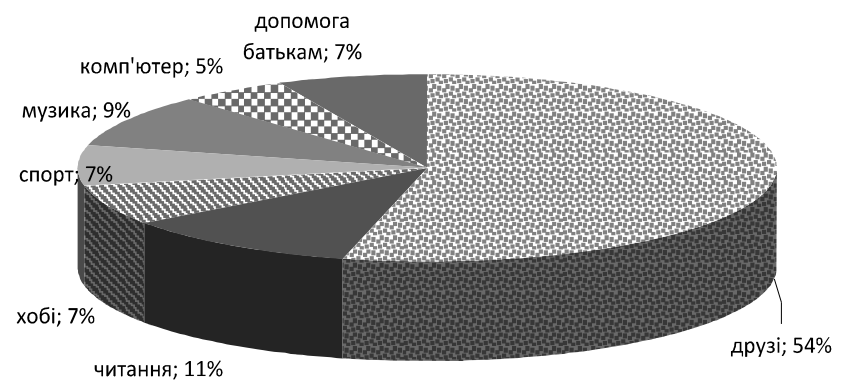

Puc. 3. Розподіл вільного часу підлітка.

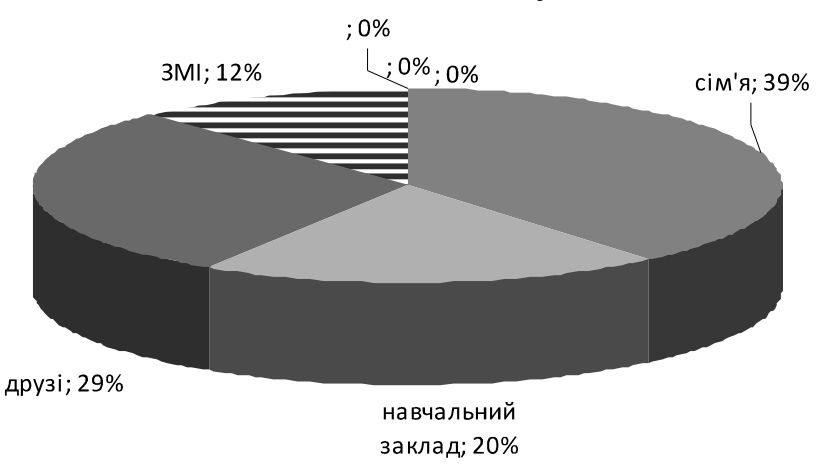

Puc. 4. Чинники, що впливають на формування світогляду у молоді

Висновки. Необхідними є два напрямки нейтралізації охарактеризованих нами соціальних факторів ризику підліткового алкоголізму: освітня профілактична робота з батьками (опікунами), яку мають проводити класні керівники, куратори, а також інформаційна політика мас-медіа, спрямована на популяризацію здорового стилю життя, а не алкогольної моди, з одночасним поширенням інформації щодо згубного впливу алкоголю на людину, особливо, дитину чи підлітка.

3. Гуляйгородська М. П. Про шкідливість нікотину, алкоголюта наркотичних речовин/М. П. Гуляйгородська// Все для вчителя. - 2004. - № 22-23. - С. 68-70.

4. Яворницький Д. І. Історія запорізьких козаків / Д. І. Яворницький. - Львів : Світ, 1990. - Т. 1. С. $173-180$. 